\title{
Incorporation versus biosynthesis of leucine: implications for measuring rates of protein synthesis and biomass production by bacteria in marine systems
}

\author{
David L. Kirchman ${ }^{1 *}$, Steven Y. Newell ${ }^{2}$ \& Robert E. Hodson ${ }^{1}$ \\ 'Department of Microbiology, University of Georgia, Athens, Georgia 30602, USA \\ ${ }^{2}$ University of Georgia Marine Station, Sapelo Island, Georgia 31327, USA
}

\begin{abstract}
Rates of leucine incorporation have been suggested recently to be useful for estimating rates of protein synthesis and biomass production by bacteria in natural water samples. We examined 2 potential problems with this approach: de novo synthesis of leucine and intracellular protein turnover Rates of leucine and methionine biosynthesis were estimated from the incorporation of ${ }^{14} \mathrm{C}$-pyruvate and ${ }^{35} \mathrm{SO}_{1}{ }^{2}$, respectively. Leucine inhibited ${ }^{14} \mathrm{C}$-pyruvate and ${ }^{3} \mathrm{H}$-glucose incorporation and methionine inhibited ${ }^{35} \mathrm{SO}_{4}$ incorporation. However, rates of biosynthesis of leucine and methionine were still much higher than the maximum rate of exogenous amino acid incorporation. This problem can be surmounted with empirically determined conversion factors which relate rates of leucine incorporation to rates of protein synthesis or biomass production. The ratio of the empirically determined factor to the theoretical factor is similar to the ratio of the rate of biosynthesis to the incorporation rate of exogenous leucine. The rate of intracellular protein turnover as determined by the pulse-chase approach was large compared with net protein synthesis in only 1 out of 5 experiments. Leucine incorporation rates are at least an underestimate of rates of protein synthesis, and in some environments may prove to be a useful measure of bacterial biomass production. Our results also indicate that the supply of dissolved amino acids may affect the uptake and mineralization of other dissolved compounds via regulation of amino acid uptake and biosynthesis.
\end{abstract}

\section{INTRODUCTION}

Recent studies of DNA synthesis by bacterial assemblages have been instrumental in demonstrating the importance of bacterioplankton in the trophic dynamics of marine systems (Fuhrman \& Azam 1980). Several investigations have shown that rates of bacterial DNA synthesis, and by implication rates of bacterial biomass production, are relatively high (reviewed by Ducklow 1983). High rates of bacterial production compared with phytoplankton production suggest that a large proportion (10 to $50 \%$ ) of primary production is processed by bacteria (reviewed by Ducklow 1983). This conclusion is supported by other measures of bacterial biomass production and carbon mineralization (Williams 1981, Larsson \& Hagström 1982).

\footnotetext{
- Present address: College of Marine Studies, University of Delaware, Lewes, Delaware 19958, USA
}

Kirchman et al. (1985) suggested that rates of protein synthesis may complement measures of DNA synthesis in studies examining bacteria in natural aquatic systems. Since a large proportion of the nitrogen in bacterial cells is protein (Ingraham et al. 1983), the rate of protein synthesis may be a more direct measure than rates of DNA synthesis of the role of bacteria in utilizing dissolved nitrogenous compounds. Furthermore, because protein is a valuable food source for higher trophic levels (Tenore et al. 1979), rates of net protein synthesis may reflect the contribution of bacteria to the nitrogen budget of bacterial grazers more accurately than rates of DNA synthesis. Finally, incorporation of leucine into protein, which is a measure of bacterial protein synthesis (Kirchman et al. 1985), may be used as an independent measure of total bacterial production.

Many laboratory studies have used leucine incorporation as an index of protein synthesis, and Kirchman 
et al. (1985) examined the applicability of this approach for natural bacterial assemblages. However, 2 problems remain to be considered before rates can be estimated accurately. Although the rate of leucine biosynthesis decreases when leucine is added to water samples from aquatic systems (Kirchman et al. 1985), it is unclear whether leucine synthesized in the presence of high extracellular concentrations (ca $10 \mathrm{nM}$ ) of leucine contributes substantially to that required for protein synthesis. If leucine biosynthesis is important, then rates of extracellular leucine incorporation would underestimate the rate of protein synthesis. Another problem not considered by Kirchman et al. (1985) is that of protein turnover. Unlike DNA, protein can be synthesized and continuously degraded (turnover) at high rates in selected growth conditions, such as during the shift from a high to a low growth rate (Ingraham et al. 1983).

The present study had 2 goals: to compare rates of leucine and methionine biosynthesis with incorporation rates of these 2 amino acids, and to compare rates of intracellular protein turnover with bacterial growth rates in a salt marsh estuary. We suggest that the regulation of amino acid biosynthesis versus assimilation of exogenous amino acids may be an important factor in determining the turnover rate of selected organic and inorganic compounds. Our results also indicate that protein turnover should be considered when the uptake of almost any compound is being examined in aquatic environments.

\section{MATERIALS AND METHODS}

Incorporation of ${ }^{3} \mathrm{H}$-leucine and ${ }^{35} \mathrm{~S}$-methionine. The basic procedure for estimating rates of protein synthesis is to measure the incorporation of ${ }^{3} \mathrm{H}$-leucine into the trichloroacetic acid (TCA) insoluble cellular material. $\left[3,4^{3} \mathrm{H}\right]$ leucine (specific activity $=60 \mu \mathrm{Ci}$ $\mathrm{nmol}^{-1}$; Amersham) was added to water samples $(10 \mathrm{ml})$ and incubated for ca 30 to $60 \mathrm{~min}$. If the isotope dilution approach is not used (see below), the addition of leucine should be $10 \mathrm{nM}$ (see 'Discussion'). Enough $50 \%$ TCA was then added to give a final concentration of $5 \%$, and the samples were heated to $85^{\circ} \mathrm{C}$ for 30 min. Once the samples had cooled, the TCA-insoluble material was collected onto Gelman filters $(0.22 \mu \mathrm{m}$ pore size) and washed twice with $5 \%$ ice-cold TCA. The filter was then treated with Protosol (New England Nuclear) or an equivalent tissue solubilizer to minimize self-absorption of the low energy beta particles. See Kirchman et al. (1985) for further details.

The procedure for measuring the incorporation of ${ }^{35} \mathrm{~S}$-methionine (specific activity $=1084 \mu \mathrm{Ci} \mathrm{nmol}{ }^{-1}$; Amersham) was the same as described above except that the filters were not treated with tissue solubilizer before radioassaying with a liquid scintillation counter TCA-killed controls were used to correct for background absorption of radioactivity for both leucine and methionine uptake.

Rates of leucine and methionine incorporation were estimated by using the isotope dilution approach of Moriarty \& Pollard (1981). Briefly, the incorporation of the radiolabeled amino acids was measured in the presence of different concentrations of nonradioactive leucine or methionine. It can be shown that the equation suggested by Moriarty \& Pollard (1981) for calculating rates is mathematically equivalent to calculation of $I_{\text {max }}$ as follows:

$$
F=\frac{I_{\max }}{\mid X \text {-intercept } \mid+A}
$$

where $F=$ the fraction of the added radioactivity incorporated per unit time (units $\mathrm{h}^{-1}$ ); $I_{\text {max }}=$ maximum incorporation rate of the exogenous amino acid; $\mathrm{A}=$ added amino acid concentration; |X-interceptl is mathematically equivalent to the isotope dilution term used by Moriarty \& Pollard (1981). The terms $I_{\max }, 1 / F$ and $\mid \mathrm{X}$-intercept $\mathrm{I}$ are analogous to $\mathrm{V}_{\max }, \mathrm{t} / \mathrm{f}$, and $(\mathrm{K}+$ S), respectively, first introduced by Wright \& Hobbie (1965). An important difference is that Wright \& Hobbie (1965) measured total uptake whereas this study and that of Moriarty \& Pollard (1981) measured incorporation into macromolecules. In addition, when corrected properly (see below), $I_{\max }$ is the actual rate of protein synthesis whereas $V_{\max }$ is the potential rate of uptake (Wright \& Hobbie 1965). The purpose of the procedure is to minimize isotope dilution and thus maximize (hence the term $I_{\max }$ ) incorporation of radioactivity into protein.

The advantage of using the $\mathrm{I}_{\text {rnax }}$ equation rather than the original equations of Moriarty \& Pollard (1981) is that the corrected (at least in terms of this dilution technique) rates can be calculated by nonlinear regression techniques ( $\operatorname{Li} 1983$ ). The nonlinear regression analysis bases the standard error of the rate on the entire data set whereas the standard error calculated by the original Moriarty \& Pollard (1981) approach would be based on the error of the IX-intercept and the error of the incorporation rate at the lowest substrate concentration.

We compared rates $\left(I_{\max }\right)$ of methionine and leucine incorporation as measured by the isotope dilution approach (Moriarty \& Pollard 1981) at different depths in a eutrophic lake (Lake Oglethorpe) near Athens, Georgia, USA in July 1984. Incorporation of a single addition of the labeled amino acid $(0.5 \mathrm{nM})$ was measured in duplicate at the following concentrations of unlabeled amino acids: 0, 5, 10, 20,50 and $100 \mathrm{nM}$. To ensure that no air was introduced into the samples, 
water was pumped up from the different depths by a hand pump. After flushing several times, the tubes were filled and capped without a headspace (final volume was $13 \mathrm{ml}$ ). The water displaced by the cap was vented out through a syringe needle. Amino acids were added via the syringe needle. This sampling procedure did not introduce measurable amounts of oxygen into samples from the anaerobic hypolimnion. The samples were incubated in situ. After a 30 min period, incorporation was stopped by adding the samples to TCA ( $5 \%$ final concentration), and subsequent extractions were completed in the laboratory.

Other than the depth profile in Lake Oglethorpe, all incubations were at the in situ temperature in darkness in the laboratory, and were initiated within $1 \mathrm{~h}$ of sample collection.

Leucine biosynthesis: pyruvate incorporation. To estimate the amount of leucine synthesized that is used for protein synthesis, the rate of ${ }^{14} \mathrm{C}$-pyruvate incorporation into the TCA-insoluble fraction was measured. Pyruvate was chosen because it is a precursor for leucine biosynthesis (Umbarger 1978). The procedure is analogous to that used for measuring leucine or methionine incorporation. $\left[3-{ }^{14} \mathrm{C}\right]$ pyruvate $(15 \mathrm{mCi}$ $\mathrm{mmol}^{-1}$; New England Nuclear) was added to water samples along with various concentrations of leucine, and the samples were incubated for 2 to $10 \mathrm{~h}$. TCA was then added and the samples were extracted as described above.

The rate of leucine synthesis was estimated by assuming that the added concentration of pyruvate 10.5 to $2 \mu \mathrm{M}$ ) was orders of magnitude higher than the in situ pyruvate concentration and that the extracellular specific activity of pyruvate was equal to the intracellular specific activity of the precursor pools for leucine biosynthesis. Since several amino acids are synthesized from pyruvate, the rate at which synthesized leucine is incorporated into protein is the rate of total pyruvate incorporation multiplied by the fraction of radioactivity, originating as ${ }^{14} \mathrm{C}$-pyruvate, that was recovered as ${ }^{14} \mathrm{C}$-leucine. This fraction in the presence of high leucine concentrations is approximately $10 \%$ (Kirchman et al. 1985). The methods for measuring this fraction as well as other aspects of these experiments are described by Kirchman et al. (1985).

One series of experiments examined the effect of leucine and phenylalanine on glucose incorporation. The only pathway by which radioactivity originating as ${ }^{3} \mathrm{H}$-glucose could be incorporated into protein is via amino acid biosynthesis and incorporation of the subsequently tritiated amino acids into protein. Thus, a decrease in glucose incorporation into the hot TCA insoluble fraction due to the addition of leucine would be consistent with the hypothesis that extracellular leucine inhibits leucine biosynthesis. These experi- ments were carried out with water samples from Marsh Landing, Sapelo Island, Georgia, USA. Leucine or phenylalanine $(0,1,5,10 \mathrm{nM})$ were added to water samples followed immediately by the addition of $1.8 \mathrm{nM}^{3} \mathrm{H}$-glucose (specific activity $33.1 \mu \mathrm{Ci} \mathrm{nmol}{ }^{-1}$; New England Nuclear). Duplicate subsamples were taken at the times indicated in 'Results' and the radioactivity incorporated into protein was measured as described above.

Methionine biosynthesis: sulfate incorporation. We compared ${ }^{35} \mathrm{SO}_{4},{ }^{3} \mathrm{H}$-leucine and ${ }^{35} \mathrm{~S}$-methionine incorporation rates into the TCA-insoluble fraction in samples from Lake Oglethorpe. Rates of ${ }^{3} \mathrm{H}$-leucine and ${ }^{35} \mathrm{~S}$-methionine incorporation were estimated by the Moriarty \& Pollard (1981) approach as described above. The rate of ${ }^{35} \mathrm{SO}_{4}$ incorporation was measured by adding $0.25 \mu \mathrm{Ci} \mathrm{ml}^{-1}$ (Amersham) and withdrawing duplicate $20 \mathrm{ml}$ subsamples every $15 \mathrm{~min}$ for $60 \mathrm{~min}$. The subsamples were extracted in TCA and treated like the ${ }^{35} \mathrm{~S}$-methionine incorporation measurements. The in situ sulfate concentration $(2.9 \mu \mathrm{M})$ was measured by ion chromatography (Dick \& Tabatabai 1979). Sulfate was separated on a HPIC-AS3 column with a $2.8 \mathrm{mM} \mathrm{NaHCO}_{3}$ to $2.2 \mathrm{mM} \mathrm{Na}_{2} \mathrm{CO}_{3}$ linear gradient. We assumed that the extracellular specific activity was equal to the intracellular specific activity of the precursor pools for methionine biosynthesis. The total rate of sulfate incorporation was corrected for the relative abundance of methionine $(2.2 \% ; \mathrm{SE}=0.12)$ versus cysteine $(1.03 \% \pm 0.090)$ in bacterial proteins (Reeck 1983).

Theorefical and empirical conversion factors for the rate of leucine incorporation. Rates of leucine incorporation must be multiplied by a 'conversion factor' in order to obtain rates of protein synthesis or cell production. A theoretical conversion factor can be calculated with information on the average molar fraction of leucine in protein $(8.8 \%$; Reeke 1983, Hagström et al. $1984)$ and the average amount of protein per bacterial cell $\left(1.2 \times 10^{-14} \mathrm{~g}\right.$ protein cell ${ }^{-1}$; assumes $50 \%$ of dry weight is protein for a cell that is $0.1 \mu^{-3}$ in size with volume to carbon conversion of $1.2 \times 10^{-13}$; Fuhrman \& Azam 1980). If leucine biosynthesis and isotope dilution are assumed to be zero, the theoretical factor is $1.1 \times 10^{17}$ cells per mole of leucine incorporation. If a high biovolume to biomass conversion factor $(5.6 \times$ $10^{-13} \mathrm{~g} \mathrm{\mu m}^{-3}$; Bratbak 1985) is used, then the leucine to cell conversion factor is $2.7 \times 10^{16}$ cells per mole of leucine incorporation. The leucine conversion factor in terms of protein is $1.5 \mathrm{~g}$ protein per mole of leucine incorporated, which is based only on the fraction of leucine in protein $(8.8 \%)$ and the molecular weight of leucine (131).

Empirical factors were estimated by the approach suggested by Kirchman et al. (1982) with water sam- 
ples from Marsh Landing, Sapelo Island. Net bacterial growth was obtained by 2 methods. The first method consisted of adding an untreated water sample to filter-sterilized water such that the particles (the bacteria and their grazers) were diluted by a factor of 10 (Fuhrman \& Azam 1980, Kirchman et al. 1982). The second method consisted of first filtering water through a $1.0 \mu \mathrm{m}$ Nuclepore filter, and then $100 \mathrm{mg} \mathrm{l}^{-1}$ of cycloheximide was added to inhibit any remaining grazers of bacteria (Newell et al. 1983). At various times, subsamples were withdrawn to measure bacterial numbers and cell size by epifluorescence microscopy (Hobbie et al. 1977), particulate protein concentrations (see below), and the incorporation rate of leucine as determined by the Moriarty \& Pollard (1981) approach (see above). The concentrations of non-radioactive leucine were $0,10,20$ and $50 \mathrm{nM}$ (each conducted in duplicate). In some experiments the incorporation of a single addition of ${ }^{3} \mathrm{H}$-leucine was measured (triplicate measurements). The incubation time for measuring leucine incorporation was $15 \mathrm{~min}$. The exact method used for any particular experiment is given in 'Results'. The conversion factor was calculated by the equations provided by Kirchman et al. (1982). Standard errors were calculated by propagation of error equations (Bevington 1969). Data on changes in bacterial abundance, biomass and incorporation rates over time were fit to exponential models as described by Kirchman et al. (1982).

In one experiment the particulate protein concentration was measured by the fluorescamine technique (Cooper 1977). Cycloheximide was added to the $<1.0$ um filtrate from salt marsh water. The hot TCA-insoluble material from triplicate $10 \mathrm{ml}$ subsamples was collected on Nuclepore filters and, after rinsing with cold $5 \%$ TCA, the filters were rinsed with $3 \mathrm{ml} 70 \%$ ethanol to remove excess TCA (Hanson \& Phillips 1981). The filters were either frozen until analysis or added directly to $1.0 \mathrm{ml} 0.1 \mathrm{~N} \mathrm{NaOH}$ and incubated overnight at $50^{\circ} \mathrm{C}$ to solubilize the protein. Borate buffer $(2.0 \mathrm{ml} ; 0.4 \mathrm{M}, \mathrm{pH}=7.0)$ was then added. While vortexing the sample $0.5 \mathrm{ml}$ fluorescamine was added. The fluorescaminc was made from a stock solution consisting of $10 \mathrm{mg}$ in $10 \mathrm{ml}$ acetone which was diluted 10 -fold in acetone before use. Fluorescence was measured in a Turner fluorometer with bovine serum albumin as the standard. Some of the problems with this measure of protein concentrations are discussed by Cooper (1979).

Protein turnover. The pulse-chase approach was used to determine if turnover of intracellular proteins occurred in marine bacterial assemblages. Samples were collected from the Duplin River at Marsh Landing, the salt marsh estuary at Sapelo Island, Georgia. Cycloheximide (100 $\left.\mathrm{mg} \mathrm{l}^{-1}\right)$ was added to water sam- ples to inhibit grazers of bacteria and to ensure that the decrease in radioactivity was due to protein turnover by the bacteria rather than metabolism of grazers that had ingested radioactive bacteria. After pre-incubation with cycloheximide for $30 \mathrm{~min},{ }^{35} \mathrm{~S}$-methionine or ${ }^{3} \mathrm{H}$-leucine was added and subsamples were withdrawn every $10 \mathrm{~min}$ and extracted in hot TCA. After $30 \mathrm{~min}$ non-radioactive methionine or leucine (concentration given with 'Results') was added to one set of samples while another set was not treated

In samples with the added chase of unlabeled amino acid, the decrease in radioactivity was analysed by plotting the ln of the fraction of radioactivity remaining in particulate protein versus time. The slope of this line is the intracellular turnover rate of bacterial protein and has units of $\mathrm{h}^{-1}$. It is important to point out that estimating the turnover rate of bacterial protein is not dependent on knowing the intracellular specific activity of methionine or leucine.

\section{RESULTS}

\section{Comparison of incorporation rates of leucine and methionine}

We compared rates of methionine incorporation with rates of leucine incorporation because methionine and leucine incorporation are often used in laboratory studies as indices of protein synthesis. The rate of leucine incorporation $\left(\mathrm{I}_{\max }\right)$ was higher than the rate of methionine incorporation by a factor of 2 to 14 (Table 1 and Fig. 1), except for 1 sample from the hypolimnion in Lake Oglethorpe (Fig. 1). Rates of leucine incorporation were probably much higher than rates of methionine incorporation because the relative abundance of leucine in bacterial proteins is higher than that of methionine; the average molar fraction of leucine is $8.8 \pm 0.23 \%$ ( $\pm \mathrm{SE}$ ) whereas the average molar fraction of methionine is $2.2 \pm 0.12 \%$ in bacterial protein (Reeke 1983). If bacteria incorporated amino acids according to their abundance in bacterial protein, the expected ratio of the leucine incorporation rate to the methionine incorporation rate is $4.0 \pm 0.24$. The observed ratio was usually lower than this expected ratio, except for 1 sample from surface waters in November (Table 1; Fig. 1)

In spite of the quantitative difference between rates of leucine and methionine incorporation, the rates covaried with depth in Lake Oglethorpe ( $r=0.92$; Fig. 1). Rates of leucine and methionine incorporation into protein (and thus the rate of protein synthesis) were highest at the metalimnion where oxygen concentrations decreased from saturation to unmeasurable levels (Fig. 1). The correlation between leucine and 
Table 1. Comparison of $\left[{ }^{3} \mathrm{H}\right]$ leucine and $\left.\left.\right|^{35} \mathrm{~S}\right]$ methionine incorporation rates in Lake Oglethorpe. Units: $\mathrm{I}_{\max }=\mathrm{nmol} \mathrm{l}^{-1} \mathrm{~h}^{-1}$; $\mid \mathrm{X}$-intercept $=\mathrm{nM}$

\begin{tabular}{|c|c|c|c|c|c|c|}
\hline \multirow[t]{2}{*}{ Date (1984) } & \multicolumn{2}{|c|}{ Leucine } & \multicolumn{3}{|c|}{ Methionine } & \multirow[b]{2}{*}{ Leu/Met ${ }^{r}$} \\
\hline & $I_{m d x}{ }^{d}$ & $\mid X$-intercept $\left.\right|^{b}$ & & $I_{\max }$ & $\mid X$-intercept $\mid$ & \\
\hline $28 \mathrm{Jul}$ & $1.38 \pm 0.066$ & $33 \pm 2.1$ & 0.44 & \pm 0.016 & $0.66 \pm 0.33$ & $3.14 \pm 0.19$ \\
\hline 6 Aug & $1.02 \pm 0.033$ & $22 \pm 0.8$ & 0.33 & \pm 0.023 & $19 \pm 2.8$ & $3.09 \pm 0.24$ \\
\hline 27 Aug & $0.023 \pm 0.017$ & $29 \pm 22$ & 0.014 & \pm 0.00048 & $19 \pm 2.1$ & $1.6 \pm 1.2$ \\
\hline 22 Nov & $0.39 \pm 0.028$ & $90 \pm 6.7$ & 0.028 & \pm 0.0045 & $1.7 \pm 0.0086$ & $14 \pm 2.5$ \\
\hline \multicolumn{7}{|c|}{ 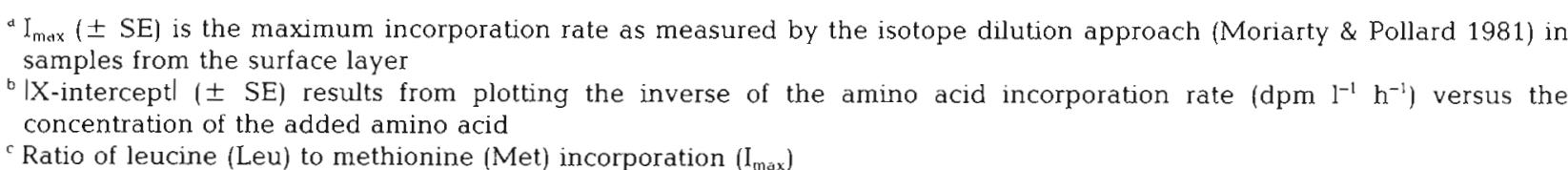 } \\
\hline
\end{tabular}

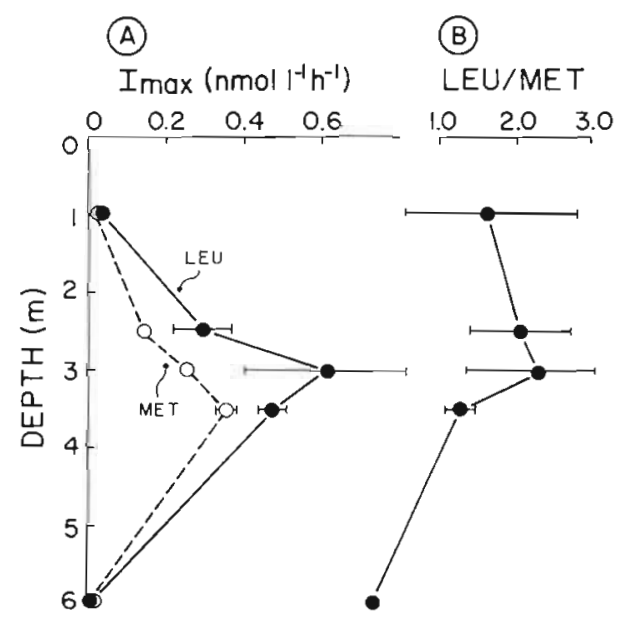

Fig. 1. (A) Depth profile of ${ }^{3} \mathrm{H}$-leucine (Leu) and ${ }^{35} \mathrm{~S}-$ methionine (Met) incorporation $\left(I_{\max }\right)$ in Lake Oglethorpe, Georgia, USA. (B) Ratio of these rates (Leu/Met). Bars are standard errors for rates determined with 6 concentrations in duplicate

methionine incorporation rates supports the hypothesis that leucine incorporation is at least a qualitative index of protein synthesis.

\section{Leucine biosynthesis versus uptake of exogenous leucine}

Kirchman et al. (1985) showed that leucine inhibited ${ }^{14} \mathrm{C}$-pyruvate incorporation, suggesting that leucine biosynthesis is inhibited by the addition of extracellular leucine, but they used high concentrations of ${ }^{14} \mathrm{C}$ pyruvate. In this investigation several experiments were conducted to examine amino acid biosynthesis with tracer levels of precursors and amino acids. When as little as $1 \mathrm{nM}$ leucine was added to seawater samples from the salt marsh estuary at Sapelo Island, ${ }^{3} \mathrm{H}$ glucose incorporation (added concentration of $1.8 \mathrm{nM}$ )

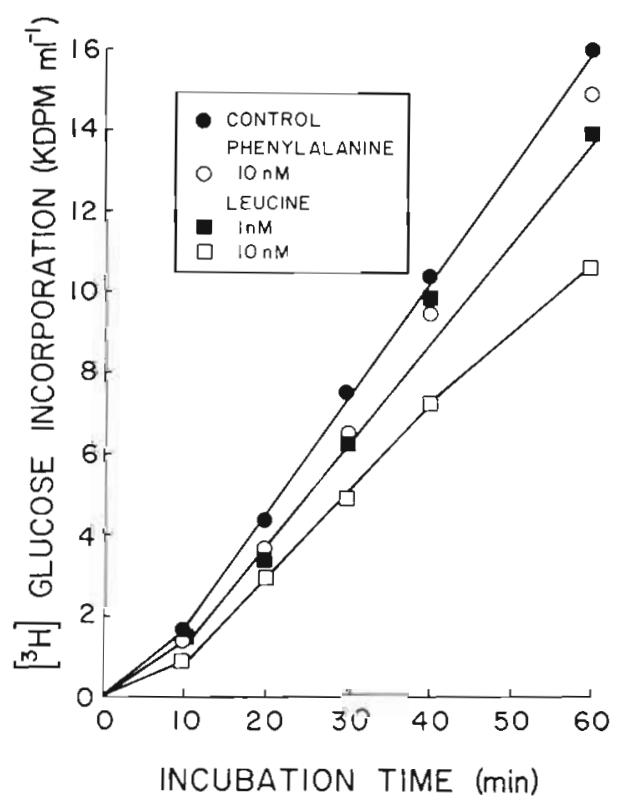

Fig. 2. Effect of leucine and phenylalanine on ${ }^{3} \mathrm{H}$-glucose $(1.8$ $\mathrm{nM}$ ) incorporation into protein (hot TCA-insoluble cell fraction) in samples from the salt marsh estuary at Sapelo Island, Georgia. Means of duplicate subsamples

into the hot TCA insoluble fraction decreased by $12 \%$; addition of $10 \mathrm{nM}$ leucine lowered glucose incorporation by $34 \%$ after $1 \mathrm{~h}$ (Fig. 2). The addition of $1 \mathrm{nM}$ leucine consistently lowered glucose incorporation in 3 out of 4 experiments; in 1 experiment the addition of $1 \mathrm{nM}$ leucine had no effect on glucose incorporation. High concentrations of leucine $(10 \mathrm{nM})$ occasionally stimulated glucose incorporation (data not shown). In contrast, the addition of $10 \mathrm{nM}$ phenylalanine only slightly $(6.2 \%)$ inhibited glucose incorporation (Fig. 2 ). These data are consistent with the hypothesis that the addition of extracellular leucine can inhibit the biosynthesis of leucine even when the precursor and amino acid are added in nanomolar concentrations. 
Table 2. Rates of leucine biosynthesis estimated from $\left[{ }^{14} \mathrm{C}\right]$ pyruvate incorporation

\begin{tabular}{|c|c|c|c|c|c|}
\hline \multirow[t]{2}{*}{ Environment } & \multicolumn{2}{|c|}{ Pyruvate } & $\begin{array}{l}\text { Leucine } \\
\text { biosynthesis }\end{array}$ & \multirow{2}{*}{$\begin{array}{l}\text { Exogenous } \\
\text { leucine } \\
\text { incorporation } \\
{ }^{c} \mathrm{~h}^{-1} \text { ) }\end{array}$} & \multirow{2}{*}{$\frac{\text { Biosynthesis }}{\text { Incorporation }}$} \\
\hline & $\begin{array}{c}\text { Turnover } \\
\text { rate } \\
\left(\% \mathrm{~h}^{-1}\right)\end{array}$ & $\begin{array}{c}\text { Uptake } \\
\text { rate }^{d} \\
\left(\text { nmol l}^{-1} h^{-1}\right)\end{array}$ & $\begin{array}{r}\text { biosynthesis } \\
\text { (nmol }\end{array}$ & & \\
\hline \multicolumn{6}{|l|}{ Sapelo Island } \\
\hline Upper & 9.6 & 80 & 24 & 10.2 & 2.3 \\
\hline Lower & 4.9 & 41 & 7.3 & 1.9 & 3.8 \\
\hline Tongue of the Ocean & 0.098 & 2.0 & 0.26 & 0.016 & 16 \\
\hline Bahamian estuary & 1.3 & 26 & 6.2 & 0.18 & 34 \\
\hline \multicolumn{6}{|c|}{$\begin{array}{l}{ }^{\mathrm{d}} \text { Uptake rate of pyruvate assumes that the added }\left[{ }^{14} \mathrm{C}\right) \text { pyruvate }(0.2 \text { to } 1.0 \mu \mathrm{M}) \text { was much greater than the in situ concentration } \\
\mathrm{b} \text { Leucine biosynthesis }=\text { (pyruvate incorporation rate into protein) } \times(\% \text { of pyruvate recovered as leucine) } \\
\left.{ }^{\mathrm{C}} \text { Exogenous leucine incorporation is } \mathrm{I}_{\max } \text { as measured by the isotope dilution approach (Moriarty \& Pollard } 1981\right) \text {. Pyruvate } \\
\text { and leucine incorporation rates were measured concurrently. The experiments at Sapelo Island were in Aug } 1983 \text { at } 2 \text { sites, } 1 \\
\text { near Marsh Landing (Lower) and } 1 \text { further up the Duplin River (Upper; see Fallon et al. in press). Samples from the Tongue } \\
\text { of the Ocean and the Bahamian estuary were taken in Oct } 1983\end{array}$} \\
\hline
\end{tabular}

It was unclear whether the rate of leucine incorporation from endogenous sources (leucine biosynthesis) was in fact lower than the incorporation rate of leucine from extracellular sources. To answer this question we estimated the rate of leucine synthesis from the rate of ${ }^{14} \mathrm{C}$-pyruvate incorporation into the hot TCA-insoluble fraction and the fraction of the ${ }^{14} \mathrm{C}$-radioactivity recovered as ${ }^{14} \mathrm{C}$-leucine after acid hydrolysis $(10 \%$; Kirchman et al. 1985). The rate of leucine synthesis and subsequent incorporation of that leucine into protein was roughly 2 to 30 -fold higher than the maximum incorporation rate of exogenous leucine (Table 2).

We next compared incorporation rates of ${ }^{3} \mathrm{H}$-leucine, ${ }^{35} \mathrm{~S}$-methionine, and ${ }^{35} \mathrm{SO}_{4}$ in Lake Oglethorpe in order to examine methionine biosynthesis, which was estimated from ${ }^{35} \mathrm{SO}_{4}$ incorporation rates corrected for the relative abundance of methionine in protein. Cycloheximide was added to inhibit eukaryotic uptake of ${ }^{35} \mathrm{SO}_{4}$. We found that the addition of methionine ( $5 \mathrm{nM}$ ) inhibited ${ }^{35} \mathrm{SO}_{4}$ incorporation into protein by $60 \%$, indicating that the addition of methionine inhibits methionine synthesis. The rate with no methionine added was 27 nmole $1^{-1} \mathrm{~h}^{-1}$ which decreased to 11 nmole $\mathrm{l}^{-1} \mathrm{~h}^{-1}$ with the addition of $5 \mathrm{nM}$ methionine. However, the rate of methionine synthesis was still much higher than the rate of exogenous leucine incorporation into protein. In this experiment methionine incorporation was very low $\left(\mathrm{I}_{\max }=0.028 \pm 0.004 \mathrm{nmol}\right.$ $\left.\mathrm{l}^{-1} \mathrm{~h}^{-1}\right)$. Even when methionine incorporation is estimated from the rate of leucine incorporation ( $\mathrm{I}_{\max }=$ $0.39 \pm 0.028 \mathrm{nmol} \mathrm{l}^{-1} \mathrm{~h}^{-1}$; see above and Table 1), methionine biosynthesis is roughly 80 -fold higher than the rate of methionine incorporation.

Our estimates of rates of leucine and methionine biosynthesis should be viewed cautiously. One problem is that we have to assume that the extracellular specific activity of the added precursor (pyruvate or $\mathrm{SO}_{4}$ ) is equal to the intracellular specific activity of the precursor immediately before synthesis of the amino acid. This assumption has to be made even when the extracellular specific activity is measured as in the case of $\mathrm{SO}_{4}$. However, the actual specific activity could only be lower (less radioactivity per mole of precursor) than the assumed specific activity, which would result in even higher calculated rates of biosynthesis. Thus, even these crude, perhaps low estimates, suggest that the ratio of biosynthesis to incorporation of exogenous amino acids is high.

\section{Conversion factors for leucine incorporation}

The empirical approach of Kirchman et al. (1982) was used to estimate conversion factors which would relate the rate of leucine incorporation to the rate of protein synthesis or cell production. Bacterial abundance and biomass increased exponentially when grazing was inhibited by the addition of cycloheximide or by diluting the particles (including the bacteria and their grazers) with filter-sterilized seawater. The rate of leucine incorporation into protein also increased exponentially. An example of these data is given in Fig. 3, and the parameters from several experiments are summarized in Table 3. During each experiment leucine incorporation followed changes in total biovolume $\left(\mu \mathrm{m}^{3} \mathrm{l}^{-1}\right)$ more closely than just cell numbers, but increases in incorporation rates and biovolumes often differed significantly (Table 3 ).

We tested the possibility that rates of leucine incorporation would track changes in bacterial protein concentrations more closely than changes in bacterial biovolumes. In one experiment rates of leucine incor- 
poration and cell biomass increased exponentially at rates of $0.14 \pm 0.027$ and $0.063 \pm 0.022 \mathrm{~h}^{-1}$, respectively. In that experiment particulate protein concen-

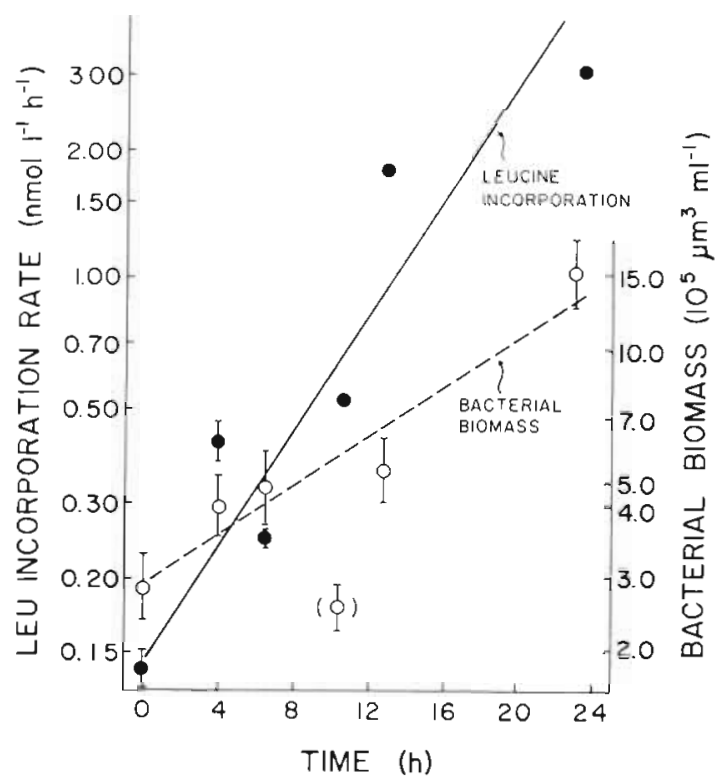

Fig. 3. Bacterial biovolume and leucine incorporation rates $\left(I_{\max }\right)$ following addition of cycloheximide to a water sample from the estuary at Sapelo Island, Georgia. Bars are standard errors. Lines are drawn from linear regression equations.

Parenthetical point was not included in the analysis trations increased by a rate of $0.12 \pm 0.032 \mathrm{~h}^{-1}$ which is not significantly different from the increase in leucine incorporation rates.

The measured protein concentration was usually higher than the protein concentration calculated from biovolumes, even when the high biovolume to carbon conversion factor was used (Table 4). These results suggest that the high biovolume to carbon conversion

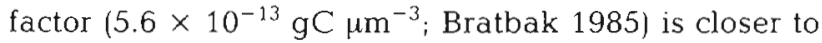
being correct than the commonly-used factor of $1.2 \times$ $10^{-13} \mathrm{gC}_{\mathrm{mm}^{-3}}$. However, there are still problems either with the fluorescamine assay (and bovine serum albumin standard) or with the biovolume to carbon conversion factor (Table 4). Nevertheless, when comparing incorporation rates with changes in protein concentrations, we need to examine only relative changes over time which could only be due to actively growing bacteria. The logarithmic changes over time would not be affected by conversion factors or problems with standardizing the protein assay. Therefore, regardless of conversion factors, these data indicate that rates of leucine incorporation and protein concentrations covary during growth of marine bacterial assemblages.

The conversion factors calculated from these experiments ranged from 1 to $84 \times 10^{17}$ cells and 1.3 to $100 \mathrm{~g}$ protein per mol of leucine incorporated (Table 3). It is

Table 3. Conversion factors for estimating rates of protein synthesis and cell production from leucine incorporation: Sapelo Island, Georgia

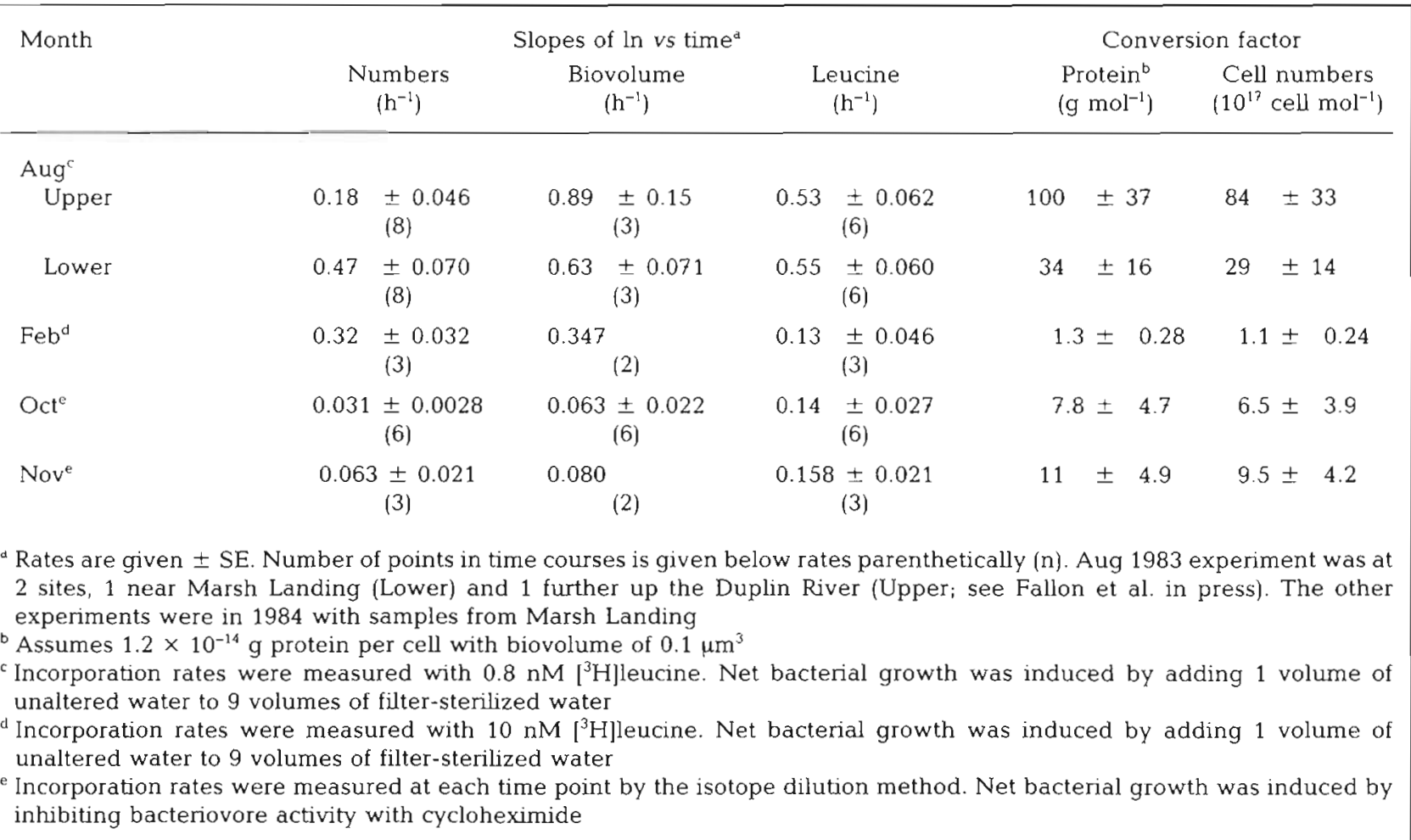


Table 4. Comparison of particulate protein concentrations as measured by the fluorescamine technique and estimated from bacterial biovolumes: Sapelo Island, Georgia ${ }^{\circ}$

\begin{tabular}{|c|c|c|c|c|}
\hline \multirow[t]{2}{*}{ Time $(\mathrm{h})$} & \multirow[b]{2}{*}{$\begin{array}{c}\text { Biovolume } \\
\left(10^{5} \mu \mathrm{m}^{3} \mathrm{ml}^{-1}\right)\end{array}$} & \multicolumn{3}{|c|}{ Particulate protein concentration $\left(\mu \mathrm{g} \mathrm{ml}^{-1}\right)$} \\
\hline & & $\begin{array}{c}\text { Fluorescamine } \\
\text { assay }\end{array}$ & Low & High \\
\hline 0 & $\begin{array}{l}2.87 \\
(0.53)\end{array}$ & $\begin{array}{c}0.0931 \\
(0.00091)\end{array}$ & 0.0347 & 0.161 \\
\hline 4 & $\begin{array}{c}4.35 \\
(0.79)\end{array}$ & $\begin{array}{c}0.248 \\
(0.029)\end{array}$ & 0.0526 & 0.244 \\
\hline 6.5 & $\begin{array}{c}4.85 \\
(0.99)\end{array}$ & $\begin{array}{c}0.823 \\
-\end{array}$ & 0.0587 & 0.272 \\
\hline 10.5 & $\begin{array}{c}2.59 \\
(0.35)\end{array}$ & $\begin{array}{c}0.795 \\
(0.031)\end{array}$ & 0.0313 & 0.145 \\
\hline 13 & $\begin{array}{c}5.31 \\
(0.91)\end{array}$ & $\begin{array}{c}1.16 \\
(0.14)\end{array}$ & 0.0642 & 0.297 \\
\hline 23.5 & $\begin{array}{l}15.3 \\
(2.8)\end{array}$ & $\begin{array}{r}1.79 \\
(0.20)\end{array}$ & 0.185 & 0.857 \\
\hline $\begin{array}{l}\text { "Bacterial biovolu } \\
\text { in Fig. } 3 \& 4 \text {. Cy } \\
\text { data are means } \\
{ }^{b} \text { Bacterial protein } \\
\text { protein } \mu \mathrm{m}^{-3} \text { ) or }\end{array}$ & $\begin{array}{l}\text { d protein concen } \\
\text { mide was added } \\
\text { given parenthe } \\
\text { ntrations were e } \\
\left(5.6 \times 10^{-13} \mu \mathrm{g}\right.\end{array}$ & $\begin{array}{l}\text { during a growth } \\
\text { um filtrate of a } \\
\text { d from biovolum } \\
\mu^{-3} \text { ) biovolume }\end{array}$ & $\begin{array}{l}\text { ther dat } \\
\text { m the sa } \\
\text { ts by ass } \\
\text { version } \mathrm{f}\end{array}$ & $\begin{array}{l}\text { ent are presented } \\
\text { Sapelo Island. All } \\
\left(1.21 \times 10^{-13} \mu \mathrm{g}\right. \\
\text { urther details }\end{array}$ \\
\hline
\end{tabular}

unclear how much of this variation in conversion factors is real. The errors calculated for these conversion factors are large, and some of the variation among the various samples is undoubtedly due to the different methods used. For example, the highest measured conversion factor was observed in an experiment with a single $0.8 \mathrm{nM}$ addition of ${ }^{3} \mathrm{H}$-leucine, whereas when a single $10 \mathrm{nM}$ addition was used the lowest conversion factor was measured (Table 3 ). In any case, it is clear that most of the empirically derived factors are substantially higher than the theoretical factor of $1.1 \times$ $10^{17}$ cells and $1.5 \mathrm{~g}$ protein per mole of leucine.

The data indicate that the isotope dilution approach (Moriarty \& Pollard 1981) does not alone give accurate estimates of protein synthesis, as evidenced here by the fact that the conversion factor based on the isotope dilution approach is significantly higher than the theoretical conversion factor which assumes no isotope dilution (Table 3). Also, the rate of protein synthesis calculated from the isotope dilution approach alone was significantly less than the change in the concentration of particulate protein (e.g. Fig. 3). Even so, the isotope dilution approach does ensure that rates of leucine incorporation are not biased by the extracellular leucine concentration, and the addition of extracellular leucine does repress leucine biosynthesis (Kirchman et al. 1985), hence minimizing intracellular isotope dilution.

The addition of tracer levels of leucine in some experiments would have resulted in very large increases in the apparent rate of leucine incorporation. For example, the turnover rate in one experiment increased at a rate of $0.29 \pm 0.051 \mathrm{~h}^{-1}$ (slope of ln[turnover rate] vs time) (Fig. 4) whereas the rate of leucine

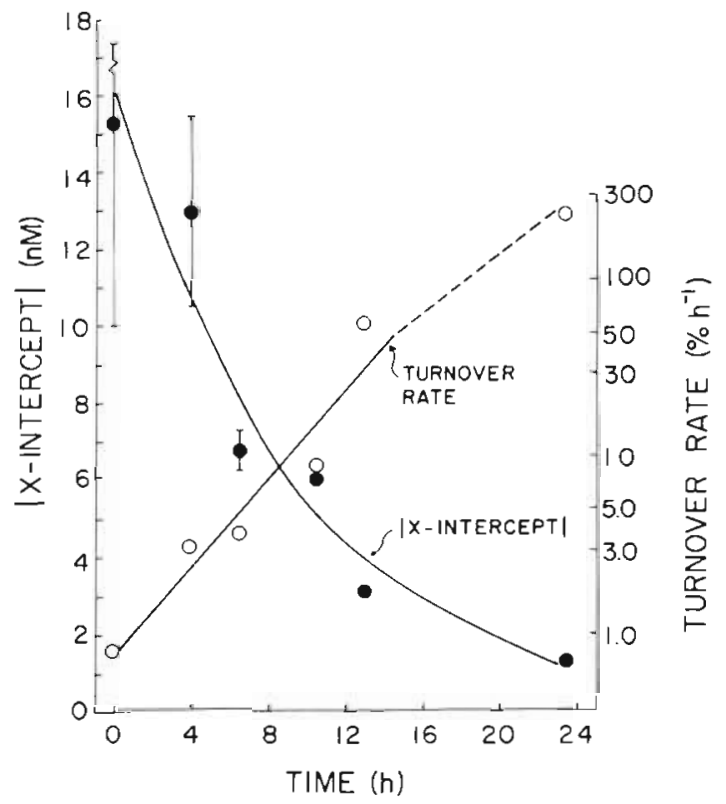

Fig. 4. Turnover rate and $\mid \mathrm{X}$-intercept $\mid$ of leucine incorporation rates following addition of cycloheximide to a water sample from the estuary at Sapelo Island, Georgia. Bars are standard errors. See Fig. 3 for $I_{\max }$ values and text for explanation of $\mid X$-intercept|. (O) Tumover rate; (-) |X-intercept| 
incorporation increased at a rate of $0.14 \pm 0.027 \mathrm{~h}^{-1}$. The increase in the turnover rate was probably due to both an increase in uptake rates (Fig. 3) and a decrease in the pool of available leucine (Fig, 4). According to isotope dilution theory (Moriarty \& Pollard 1981), the $\mid \mathrm{X}$-intercept $\mid$ is a measure of this leucine pool. Thus, the sum of the change in $I_{\max }\left(0.14 \pm 0.027 \mathrm{~h}^{-1}\right)$ and in the apparent pool size ( $\mathrm{X}$-interceptl) $\left(0.11 \pm 0.01 \mathrm{~h}^{-1}\right.$ ) was equal to the change in the turnover rate $(0.29 \pm$ $0.051 \mathrm{~h}^{-1}$ ).

\section{Intracellular turnover of bacterial protein}

To determine if intracellular turnover of bacterial protein occurs, pulse-chase experiments were conducted with ${ }^{3} \mathrm{H}$-leucine and ${ }^{35} \mathrm{~S}$-methionine added to water samples from the salt marsh estuary at Sapelo Island. Cycloheximide was added to minimize turnover by eukaryotic grazers of labeled bacterial protein. An example of data obtained from our pulse-chase experiments is given in Fig. 5 and the results from several experiments are summarized in Table 5. As expected, accumulation of radioactivity into protein increased linearly over time (Fig. 5). When the 'chase' of non-radioactive methionine or leucine was added there was usually an exponential decrease in radioactivity in cellular protein. The rate of intracellular protein turnover varied from 0.012 to $0.311 \mathrm{~h}^{-1}$ (Table 5).

The turnover rates in August were small compared to the growth rates of the bacterial assemblage in samples from the salt marsh at Sapelo Island. The rate of $0.103 \pm 0.014 \mathrm{~h}^{-1}$ measured on August 30 was probably artificially high since there was a $30 \mathrm{~min}$ lag

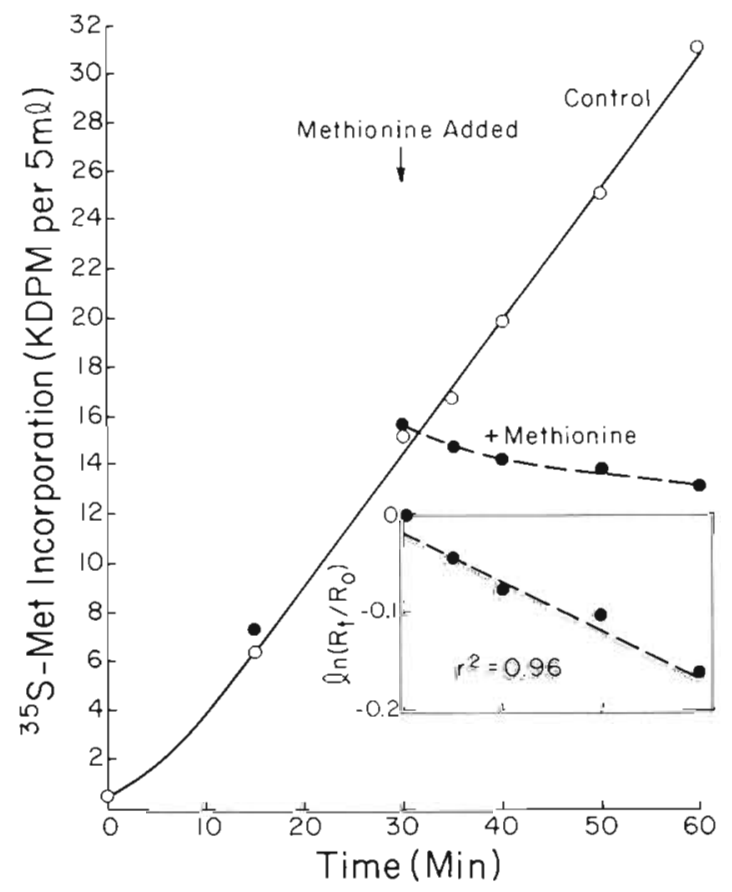

Fig. 5. Pulse-chase experiment to measure the rate of protein turnover by bacterial assemblages in a water sample from Sapelo Island, Georgia. Means of duplicate subsamples. At the time indicated by the arrow the chase of $1 \mu \mathrm{M}$ methionine (Met) was added to 1 set of samples. Inset shows log plot used to calculate turnover rates which is based on the radioactivity at time $=t\left(R_{t}\right)$ divided by the radioactivity just before addition of the chase $\left(R_{0}\right)$

before turnover was measurable. The one turnover rate measured in September with ${ }^{35} \mathrm{~S}$-methionine is high $\left(0.311 \mathrm{~h}^{-1}\right)$. This rate implies that approximately $75 \%$ (assuming a growth rate of $0.1 \mathrm{~h}^{-1}$ [Table 3] gives 0.3 /

Table 5. Summary of pulse-chase experiments to measure intracellular protein turnover by bacteria in samples from Marsh Landing, Sapelo Island, Georgia

\begin{tabular}{|c|c|c|c|c|c|}
\hline \multirow[t]{2}{*}{ Date } & \multirow[t]{2}{*}{ Amino acid ${ }^{a}$} & \multicolumn{2}{|c|}{ Turnover } & \multirow[t]{2}{*}{$n^{b}$} & \multirow[t]{2}{*}{$t$-test ${ }^{c}$} \\
\hline & & Rate & Error & & \\
\hline 19 Aug & Leucine $(10 \mu \mathrm{M})$ & 0.012 & 0.0054 & 7 & $p<0.05$ \\
\hline $20 \mathrm{Aug}$ & $\begin{array}{l}\text { Leucine }(100 \mu \mathrm{M}) \\
\text { Control }(0 \mu \mathrm{M})^{\mathrm{d}}\end{array}$ & $\begin{array}{l}0.028 \\
0.022\end{array}$ & $\begin{array}{l}0.015 \\
0.025\end{array}$ & $\begin{array}{l}4 \\
4\end{array}$ & $\begin{array}{l}\text { ns } \\
\text { ns }\end{array}$ \\
\hline 30 Aug & Methionine $(1.0 \mu \mathrm{M})^{\mathrm{e}}$ & 0.103 & 0.014 & 4 & $p<0.005$ \\
\hline $11 \mathrm{Sept}$ & Methionine $(1.0 \mu \mathrm{M})$ & 0.311 & 0.029 & 5 & $\mathrm{p}<0.001$ \\
\hline \multicolumn{6}{|c|}{$\begin{array}{l}{ }^{a} \text { Pulse-chase experiments were conducted either with }{ }^{3} \mathrm{H} \text {-leucine or }{ }^{35} \mathrm{~S} \text {-methionine. Concentration given parenthetically is } \\
\text { that of the chase or the added unlabeled amino acid } \\
{ }^{b} \text { Number of time points with duplicate subsamples is given as } \mathrm{n} \\
{ }^{\mathrm{C}} 1 \text {-tail Student's t-test of rate }>0 \text {. ns = not significantly different from zero }(\mathrm{p}>0.05) \\
{ }^{\mathrm{d}} \text { In the control without the added unlabeled leucine, uptake stopped because of depletion of the isotope, and radioactivity } \\
\text { incorporated into protein decreased due to protein turnover } \\
{ }^{\mathrm{e}} \text { In this experiment, the protein turnover rate was zero (no measurable decrease in radioactivity incorporated into protein) for } \\
30 \mathrm{~min} \text { after addition of the } 1.0 \mu \mathrm{M} \text { methionine chase. After } 30 \text { min radioactivity declined by the rate given in the table }\end{array}$} \\
\hline
\end{tabular}


0.4) of total protein synthesis was uncoupled from growth. It is possible that the turnover rate based on ${ }^{3} \mathrm{H}$-leucine incorporation would be low in September as observed in August, although there is no reason why use of ${ }^{3} \mathrm{H}$-leucine and ${ }^{35} \mathrm{~S}$-methionine should give different estimates of the rate of protein turnover, unless these compounds are assimilated by different bacteria. It is more likely that rates of protein turnover vary with environmental and physiological conditions. Since most of the turnover rates were low compared to bacterial growth rates, we tentatively conclude that usually protein turnover was only a small portion of total protein synthesis by bacterial assemblages in the salt marsh during late summer.

\section{DISCUSSION}

Rates of leucine incorporation into the hot TCAinsoluble cell fraction provide, at the very least, an underestimate of the rate of protein synthesis by natural bacterial assemblages (Kirchman et al. 1985). A large fraction of the bacterial assemblage assimilates leucine and other amino acids in many environments (Fuhrman \& Azam 1982, Tabor \& Neihof 1984, Kirchman et al. 1985). Even at high concentrations, leucine is not transformed to other compounds that are incorporated into macromolecules insoluble in hot TCA, although some nonspecific incorporation may occur in oligotrophic environments (Kirchman et al. 1985). Therefore, in most cases the rate of leucine incorporation will not overestimate the rate of protein synthesis. The molar fraction of leucine in bacterial protein is quite constant (Reeke 1983) such that any change in the rate of leucine incorporation will reflect changes in rates of protein synthesis, not in the amount of leucine in bacterial protein.

Although the thymidine (Fuhrman \& Azam 1980) and leucine (Kirchman et al. 1985) approaches are complementary measures of different aspects of bacterial metabolism, it may be useful to compare the two as measures of total bacterial production. In theory, the thymidine approach is clearly superior. Thymidine is incorporated primarily into DNA when cells are synthesizing DNA, which is closely coupled to cell division and thus new cell production. Leucine, on the other hand, potentially can be incorporated into protein even if net protein synthesis and cell production were zero (Ingraham et al. 1983). Furthermore, during 'shift-ups' from low to high growth rates, rates of protein synthesis can be high relative to cell production (Ingraham et al. 1983). Finally, although Kirchman et al. (1985) did not observe with microautoradiography any uptake of leucine by phytoplankton, leucine is more likely to be assimilated by phytoplankton (in particular cyanobacteria) than thymidine (e.g. Fuhrman \& Azam 1982).

In practice the leucine approach may be more informative than the thymidine approach for estimating bacterial biomass production in selected environments. There are at least 3 potential difficulties with the thymidine technique not encountered with the leucine approach. (1) In some environments, nonspecific incorporation of thymidine into protein and RNA can be substantial (Ducklow et al. 1985, Hanson \& Lowery 1983, R. D. Fallon pers. comm.). This necessitates isolation of DNA, which is tedious and not without problems with samples from natural aquatic environments (Riemann 1984). (2) The extent to which thymidine biosynthesis could lead to underestimates of DNA synthesis has not be adequately addressed. Only 1 study (Fuhrman \& Azam 1982) has attempted to estimate thymidine biosynthesis with an approach independent of ${ }^{3} \mathrm{H}$-thymidine incorporation rates. (3) Microautoradiography studies have shown that the number of bacteria labeled with ${ }^{3} \mathrm{H}$-thymidine can be substantially lower than the number labeled with ${ }^{3} \mathrm{H}$ amino acids (Douglas 1985, Tabor and Neihof 1984). Although amino acid assimilation by nondividing bacteria could cause this difference, it is possible that a significant number of actively-dividing bacteria do not assimilate thymidine but do assimilate leucine in selected environments.

The conversion factors for thymidine and leucine incorporation undoubtedly vary with environmental conditions. When the high conversion factors measured with low leucine additions are discarded, we found that the factor varied from 1.1 to $9.5 \times 10^{17}$ cells mole $^{-1}$. If a single conversion factor were to be used as the 'literature value', we recommended the median of this range or $5.4 \times 10^{17}$ cells mole ${ }^{-1}$. We have found $10 \mathrm{nM}$ leucine is often adequate to 'swamp' the in situ concentration which usually is ca $1 \mathrm{nM}$ (e.g. Carlucci et al. 1984). But during the initial stages of investigating an aquatic ecosystem, we recommend the use of the isotope dilution approach (Moriarty \& Pollard 1981) which ensures that variation in the extracellular concentration of leucine does not affect the measured incorporation rates and helps minimize isotope dilution due to intracellular pools.

The empirical conversion factor of $5.4 \times 10^{17}$ cells mole $e^{-1}$ is 4.9 -fold higher than the theoretical conversion factor of $1.1 \times 10^{17}$ cells mole ${ }^{-1}$, which was calculated assuming that leucine biosynthesis and isotope dilution were zero. Our estimated rates of leucine biosynthesis are high enough to account for the difference between the theoretical and empirical factors. In fact, the ratio of biosynthesis to incorporation of leucine or methionine was often very high, with some values as high as 80 . Based on this ratio we would have 
Table 6. Summary of studies showing inhibition of amino acid biosynthesis by addition of amino acids. Incorporation of a radiolabeled precursor into the hot TCA-insoluble fraction was measured after the addition of the indicated amino acid. Monheimer (1979) measured total uptake

\begin{tabular}{|llcc|}
\hline Environment & Precursor/amino acid & \% Inhibition & Source \\
\hline Bahamian estuary & Pyruvate/leucine & $25-40$ & Kirchmann et al. 1985 \\
Tongue of Ocean & Pyruvate/leucine & 53 & Kirchmann et al. 1985 \\
Sapelo Island, Georgia & Pyruvate/leucine & 40 & Kirchmann et al. 1985 \\
Sapelo Island, Georgia & Glucose/leucine & $12-34$ & This study \\
Lake Oglethorpe, Georgia & Sulfate/methionine & 60 & This study \\
Canadargo Lake, New York & Sulfate/methionine + cysteine & $0-50$ & Monheimer (1979) \\
Lake Georgia, New York & Sulfate/methionine + cystene & $0-50$ & Monheimer (1979) \\
\hline
\end{tabular}

predicted much lower inhibition of amino acid precursor incorporation (e.g. pyruvate) with the addition of amino acids.

Table 6 summarizes the studies that have examined the effect of amino acid additions on the uptake of potential amino acid precursors. The following example illustrates the relation between the ratio of biosynthesis to incorporation and the inhibition of precursor incorporation by the addition of amino acids. Assume that all leucine for bacterial protein is synthesized de novo in the absence of added leucine. When leucine is added biosynthesis decreases and precursor incorporation (e.g. pyruvate) is inhibited by $33 \%$, a value which has been measured frequently (Table 6). In this case, the ratio of biosynthesis to incorporation after the amino acid addition would be 66 to 33 , that is, 2 . In other words, the ratio of biosynthesis to incorporation is probably on the order of 5 (the ratio of the empirical to the theoretical conversion factor) rather than 50 .

The potential effects of protein turnover should be taken into account when the uptake of almost any compound is being measured. Although incorporation of a variety of compounds into protein has not been examined extensively, many compounds are probably incorporated into protein because of the high protein content of bacterial cells. Cuhel et al. (1983) observed that a high proportion of glucose is incorporated into protein. Protein turnover could lead to overestimating net incorporation and underestimating percent respiration of many compounds. Radioactivity could be incorporated into protein even if the net rate of protein synthesis were zero as a result of protein turnover. Since the specific activity of protein would be low during short incubations even with high rates of net protein synthesis, respiration (or excretion of byproducts) of the degraded protein would appear to be low, if the data were not analyzed properly, because of the low amount of radioactivity lost (King \& Berman 1984).

It has been suggested that much of total bacterial production is supported by assimilation of dissolved free amino acids (Ferguson \& Sunda 1984, Lancelot \& Billen 1984). That hypothesis is not consistent with the high rates of leucine and methionine biosynthesis estimated here. However, it is possible that bacterial assemblages obtain nearly all their necessary carbon and nitrogen from amino acids other than leucine and methionine. These 2 amino acids do not occur in high concentrations in the dissolved pool (e.g. Mopper \& Lindroth 1982) and high rates of de novo synthesis may be required. On the other hand, recent studies (Laws et al. 1985, Wheeler \& Kirchman 1986) have observed relatively high rates of ammonium assimilation by heterotrophic bacteria, which is consistent with the high rates of amino acid biosynthesis estimated here. Since ammonium assimilation would be used predominately for amino acid biosynthesis and subsequent incorporation into protein, high ammonium assimilation rates by bacteria imply that rates of amino acid biosynthesis are substantial and that bacteria obtain carbon and nitrogen from compounds other than amino acids. Clearly more work is needed on the relative importance of different, carbon and nitrogen sources for bacterial growth in marine environments.

Information about rates of amino acid biosynthesis is important for understanding the roles of bacteria in marine trophic dynamics and the impact of bacteria on dissolved organic and inorganic compounds. We expect that bacterial assemblages utilizing extracellular amino acids for protein synthesis would have higher growth rates and growth efficiencies than bacterial assemblages synthesizing amino acids from other organic and inorganic compounds. Amino acid biosynthesis is energetically more costly than transport (Ingraham et al. 1983). Growth rates and growth efficiencies determine the amount of material that is passed onto higher trophic levels via the 'microbial loop' (Azam et al. 1983). Furthermore, the production and concentration of extracellular amino acids versus rates of amino acid biosynthesis could affect assimilation rates of important inorganic compounds (e.g. ammonium) and organic compounds (e.g. glucose) that 
are used in amino acid biosynthesis. In short, the regulation of amino acid uptake and biosynthesis may, to a large extent, explain changes in rates of uptake and mineralization of selected compounds and ultimately bacterial growth and production in marine waters.

Acknowledgements. We thank T Strickland and J. Ash for the measurements on sulfate concentrations and R. S. Alberte and $\mathrm{R}$. Fallon for critically reviewing the manuscript. A first draft was written while D. K. was a visiting scientist at the Max-Planck-Institut für Limnologie, Plön, FRG. He thanks J. Overbeck and the Max-Planck Society for their support and $M$. Höfle for many stimulating discussions. This research was supported by NSF grant OCE 8117834 and NOAA Sea Grant NA 80AA-D-0091 awarded to R.E.H. and by NSF grant BSR8407928 awarded to K. G. Porter and D.L.K.

\section{LITERATURE CITED}

Azam, F., Fenchel, T., Field, J. G., Gray, J. S., Meyer-Reil, L. A., Thingstad, F. (1983). The ecological role of watercolumn microbes in the sea. Mar. Ecol. Prog. Ser. 10: $257-263$

Bevington, P. R. (1969). Data reduction and error analysis for the physical sciences. McGraw Hill, New York

Bratbak, G. (1985). Bacterial biovolume and biomass estimations. Appl. environ. Microbiol. 49: 1488-1493

Carlucci, A. F., Craven, D. B., Henrichs, S. M. (1984). Diel production and microheterotrophic utilization of dissolved free amino acids in waters off southern California. Appl. environ. Microbiol. 48: 165-170

Cooper, T. G. (1977). The tools of biochemistry. Wiley-Interscience. New York

Cuhel, R. L., Jannasch, H. W., Taylor, C. D. (1983). Microbial growth and macromolecular synthesis in the northwestern Atlantic Ocean. Limnol. Oceanogr. 28: 1-18

Dick, W. A., Tabatabai, M. A. (1979). Ion chromatographic determination of sulfate and nitrate in soils. Soil Sci. Soc. Amer. J. 43: 899-904

Douglas, D. J. (1985). Autoradiography-based enumeration of heterotrophic and phototrophic picoplankton with estimates of bacterial production and growth rates. EOS (Trans. Am. Geophys. Un.) 66: 1323

Ducklow, H. W. (1983). Production and fate of bacteria in the ocean. Bioscience 33: 494-501

Ducklow, H. W., Hill, S. M., Gardner, W D. (1985). Bacterial growth and the decomposition of particulate organic carbon collected in sediment traps. Cont. Shelf Res. 4: 445-464

Fallon, R. D., Newell, S. Y., Sherr, B. F., Sherr, E. G., (in press) Factors affecting bacterial biomass and growth in the Duplin River estuary and coastal Atlantic Ocean. Proc 2nd. International Colloquium of Marine Bacteriology

Ferguson, R. L., Sunda, W G. (1984). Utilization of amino acids by planktonic marine bacteria: Importance of clean technique and low substrate additions. Limnol. Oceanogr 29: $258-274$

Fuhrman, J., Azam, F. (1980). Bacterioplankton secondary production estimates for coastal waters of British Columbia, Antarctica, and California. Appl. environ. Microbiol. 39: 1085-1095

Fuhrman, J., Azam, F. (1982). Thymidine incorporation as a measure of heterotrophic bacterioplankton production in marine surface waters: evaluation and field results. Mar. Biol. 66: 109-120
Hagstrom, A., Ammerman, J. W., Henrichs, S., Azam, F (1984). Bacterioplankton growth in seawater Il. Organic matter utilization during steady-state growth in seawater cultures. Mar. Ecol. Prog. Ser. 18: 41-48

Hanson, R. S., Phillips, J. A. (1981). Chemical composition. In: Gerhardt, P., Murray, R. G. E., Costilow, R. N. (ed) Manual of methods for general bacteriology. American Society for Microbiology, Washington, D.C. p. 328-364

Hanson, R. B., Lowery, H. K. (1983). Nucleic acid synthesis in oceanic microplankton from the Drake Passage, Antarctica: evaluation of steady-state growth. Mar Biol. 73: $79-89$

Hobbie, J. E., Daley, R. J., Jasper, S. (1977). Use of Nuclepore filters for counting bacteria by fluorescence microscopy. Appl. environ. Microbiol. 33: 1225-1228

Ingraham, J. L., Maaløe, O., Neidhardt, F. C. (1983). Growth of the bacterial cell. Sinauer Assoc., Sunderland, Massachusetts

King, G. M., Berman, T. (1984). Potential effects of isotopic dilution on apparent respiration in ${ }^{14} \mathrm{C}$ heterotrophy experiments. Mar. Ecol. Prog. Ser. 19: 175-180

Kirchman, D., Ducklow, H. W., Mitchell, R. (1982). Estimates of bacterial growth from changes in uptake rates and biomass. Appl. environ. Microbiol. 44: 1296-1307

Kirchman, D., K'nees, E., Hodson, R. (1985). Leucine incorporation and its potential as a measure of protein synthesis by bacteria in natural aquatic systems. Appl. environ Microbiol. 49: 599-607

Lancelot, C., Billen, G. (1984). Activity of heterotrophic bacteria and its coupling to primary production during the spring phytoplankton bloom in the southem bight of the North Sea. Limnol. Oceanogr. 29: 721-730

Larsson, U., Hagström, Å. (1982). Fractionated phytoplankton primary production, exudate release and bacterial production in a Baltic eutrophication gradient. Mar Biol. 67: $57-70$

Laws, E. A., Harrison, W. G., DiTullio, G. R. (1985). A comparison of nitrogen assimilation rates based on ${ }^{15} \mathrm{~N}$ uptake and autotrophic protein synthesis. Deep Sea Res. 32: 85-95

Li, W. K. W. (1983). Consideration of errors in estimating kinetic parameters based on Michaelis-Menten formalism in microbial ecology. Limnol. Oceanogr. 28: 185-190

Monheimer, R. H. (1979). Effect of cysteine and methionine on sulfate uptake and primary production by axenic algal cultures and lake microplankton communities. J. Phycol. 15: $284-288$

Mopper, K., Lindroth, P. (1982). Diel and depth variations in dissolved free amino acids and ammonium in the Baltuc Sea determined by shipboard HPLC analysis. Limnol. Oceanogr. 27 : 336-347

Moriarty, D. J. W., Pollard, P. C. (1981). DNA synthesis as a measure of bacterial productivity in seagrass sediments. Mar Ecol. Prog. Ser. 5: 151-156

Newell, S. Y., Sherr, B. F., Sherr, E. B., Fallon, R. D. (1983) Bacterial response to presence of eukaryote inhibitors in water from a coastal marine environment. Mar. environ. Res. 10: 147-157

Reeck, G. R. (1983). Amino acid compositions of selected proteins. In: Laskin, A. I., Lechevalier, H. A. (ed.) Handbook of microbiology, Vol. 2. Microbial composition. CRC Press, Inc., Boca Raton, p. 15-29

Riemann, B. (1984). Determining growth rates of natural assemblages of freshwater bacteria by means of ${ }^{3} \mathrm{H}$-thymidine incorporation into DNA: comments on methodology. Ergebn. Limnol. 19: 67-80

Tabor, P. S., Neihof, R. A. (1984). Direct determination of 
activities for microorganisms of Chesapeake Bay populations. Appl. environ. Microbiol. 48: 1012-1019

Tenore, K. R., Hanson, R. B., Dornseif, B. E., Wiederhold, C. N. (1979). The effect of organic nitrogen supplement on the utilization of different sources of detritus. Limnol. Oceanogr. $24: 350-355$

Umbarger, H. E. (1978). Amino acid biosynthesis and its regulation. Ann. Rev. Biochem. 47: 533-606
Wheeler, P. A., Kirchman, D. L. (1986). Utilization of inorganic and organic nitrogen by bacteria in marine systems. Limnol. Oceanogr. 31: (in press)

Williams, P. J. leB. (1981). Microbial contribution to overall marine plankton metabolism: direct measurements of respiration. Oceanologica Acta 4: 359-364

Wright, R., Hobbie, J. E. (1965). Uptake of organic solutes in lake water. Limnol. Oceanogr 10: 22-28

This article was presented by Professor K. Banse; it was accepted for printing on May 20, 1986 